\title{
CAUSALITY RELATIONSHIP OF FINANCING, POVERTY, UNEMPLOYMENT, CONSUMER PRICE INDEX AND ECONOMIC GROWTH IN INDONESIA
}

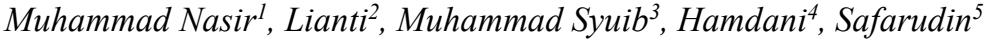 \\ Email :nasiraceh@pnl.ac.id,safaruddin@pnl.ac.id
}

\begin{abstract}
This study aims to analyze the effect of financing and unemployment on economic growth in Indonesia. This study was conducted in 33 provinces over a period of 7 years from 2011-2017. The data analysis tool used is the Vector Error Correction Model (VECM) panel. These results prove that all variables such as financing, poverty, unemployment and the consumer price index have an effect on economic growth in Indonesia. There is sufficient evidence that financing, poverty, unemployment and the consumer price index are closely related to economic growth. The recommendation from this research is that Islamic banking can increase financing as an effort to improve the economy. As for the government, they are urged to control the level of poverty and unemployment,
\end{abstract}

Keywords : Economic Growth, Financing, Poverty, Unemployment, Consumer Price Index and VECM.

\section{INTRODUCTION}

Economic growth is one of the important indicators in measuring the progress or welfare of a country. In general, the direct factors that affect economic growth are macro indicators. Macroeconomic indicators consist of labor force participation, inflation, and human development index, poverty, unemployment, domestic income, gross regional product per capita and consumption per capita.

In addition, economic growth cannot be separated from indirect factors. Indirect factors are also important indicators that affect economic growth according to Florin Teodor Boldeanu and Liliana Constantinescu (2015). These indirect factors relate to financial institutions, private administrations, etc.), the size of aggregate demand, the level of savings and investment, the efficiency of the financial system, budgetary and fiscal policies, labor and capital migration, and government efficiency.
Indirect factors are generally related to financing. Financing is an activity carried out by the financial sector which is also in the Islamic economic system. Financing is an alternative way in all transactions based on risk and profit sharing (Prastowo, 2018). In the context of Indonesia, the development of financing carried out by Islamic banking has experienced rapid development. Furqani and Mulyani (2009) argue that at least this development is driven by demand and supply, so that economic growth is also encouraged. Almost all provinces in Indonesia to date have implemented this financing activity. The speed of financing is expected to be able to provide sustainable solutions for both the short and long term (Tabash \& Dhankar, 2014).

The number of Islamic bank offices in the form of Sharia Commercial Banks (BUS), Sharia Business Units (UUS) and Sharia People's Financing Banks (BPRS) based on Sharia Banking Statistics Data until August 2018 has reached 2,470 offices spread throughout Indonesia (OJK), 2018). Various types of financing provided by BUS and UUS in the same period have reached $\mathrm{Rp} 303.5$ 
Trillion. $27.65 \%$ of the total financing was allocated for working capital financing, $21.87 \%$ was allocated for investment financing and the rest for consumption financing. When viewed specifically from the education services sector, as part of the total funding, the funding for this extraordinary education services sector only has a very small portion, which is only $1.69 \%$. Based on other data, BPS Indonesia shows an increase in financing in Indonesia during the 2010-2017 period.The trend of declining economic growth in 33 provinces in Indonesia. Financing, on the other hand, continues to increase. In line with economic growth in Indonesia, unemployment has tended to decline since 2010-2017. However, the decline was faster than economic growth, although it tends to fluctuate. not much different from the variation in economic growth between provinces. This situation shows the contribution of financing to economic growth in Indonesia.

\section{Literature Review}

The Effect of Financing on Economic Growth

Muhamad Abduh and Mohd Azmi Omar (2012) investigated the relationship of Islamic banks and economic growth in Indonesia in both the short and long term using a bound testing approach of the cointegration model and error correction, which was developed in the autoregressive distributed lag (ARDL) framework. The results showed a significant short-term and long-term relationship between Islamic banks and economic growth in Indonesia. They further said that there is a two-way relationship in both supply-leading Schumpeter and Robinson's demand-following between Islamic banks and economic growth in Indonesia.

Furqani and Mulyany (2009) examined the dynamic relationship between Islamic banks and economic growth in Malaysia using cointegration tests and vector error correction models. The results show that only the causes of fixed investment in Islamic banks for the period 1997: 1 to 2005: 4. In the long term there is evidence of a two-way relationship between Islamic banks andfixed investment in Malaysia. They further said that there is evidence that an increase in GDP will develop Islamic banks and not the other way around.

Farahani and Sadr (2012) examined the relationship between Islamic banks and economic growth in Indonesia and Iran both in the short and long term using a cointegration and error correction bound testing approach, which was developed within the autoregressive distribution lag (ARDL) framework. The results show that there is a significant relationship both in the short and long term between Islamic banks and economic growth in Indonesia and Iran. They further said that this relationship is a two-way relationship.

Farahani and Dastan (2013) examined the relationship between Islamic banks and economic growth in Malaysia, Indonesia, Bahrain, UAE, Saudi Arabia, Egypt, Kuwait, Qatar and Yemen using the panel cointegration approach model framework. In general, it shows that there is a positive and significant relationship between Islamic banks and economic growth in these countries. They further said that this relationship was stronger in the long run than in the short term.

The Effect of Unemployment on Economic Growth

The economic activities of a country are aimed at maximizing the level of prosperity of its people and always achieving sustainable economic growth. This target cannot be achieved if the unemployment rate is relatively high. The high unemployment rate will cause various negative impacts, both on economic stability and socio-political stability.

The impact on economic stability, unemployment can disrupt economic stability which will reduce or weaken Aggregate Demand (AD) and Aggregate Supply (US). A higher unemployment rate will reduce the income received by the community. The decline in the US will reduce business activity so that it will push production levels to a lower direction and in the end the US will also fall. This means that the number of national products available and ready to be supplied will be increasingly limited and increasingly scarce, thus triggering an increase in the price level. In addition, the US shortage will exacerbate the situation as it can lead to greater business downsizing and will lead to a higher unemployment rate.

The decline of the Army and the US will clearly threaten economic stability. This has been proven time and time again in the history of the world economy. The Great Depression (1929-1937), for example, recognized by economists as a result of a decline in aggregate demand, the East Asian economic crisis (1998), including what Indonesia has experienced, according to the World Bank and IMF (1998), can be explained in the context of the interaction decrease in Aggregate Demand (AD) and Aggregate Supply (US).

Kreishan (2011) investigated the relationship between unemployment and economic growth applying Okun's law in Jordan using annual data 
from 1970 to 2008 . The time series technique was used to examine the relationship between unemployment and economic growth and to obtain the level of Okun's coefficient. In addition, this study also applies Augmented Dickey-Fuller (ADF) for unit root and cointegration testing. The empirical results of his research show that Okun's law is confirmed in the case in Jordan. This means that the low rate of economic growth cannot answer the unemployment problem in Jordan.

In a more recent study, Imran et al. (2015) examined the relationship between unemployment and economic growth in 12 Asian countries from 1982 to 2011. They conducted an empirical analysis using Fixed Effects and Pooled OLS techniques using a panel data set to measure individual country effects, group effects and time effects at the time of year. the same one. time examines the relationship between unemployment and economic growth. They consistently find high unemployment rates leading to a decline in economic growth across all models. The economic growth of developing countries in Asia is influenced by the unemployment rate, especially in several Asian countries such as India, Indonesia, Sri Lanka, and Thailand which have the highest unemployment rates compared to other Asian countries studied.

Sadiku et al. (2015) aims to empirically estimate the relationship between unemployment and economic growth in FYR Macedonia using Okun's Law. They conducted an empirical analysis using four models, namely the difference model, dynamic model, ECM, and the VAR estimation approach, taking into account the relationship between unemployment and economic growth in both the short and long term. The data set used is quarterly data from the period 2000 to 2012. The empirical results of their study show that the four models do not show strong evidence and cannot confirm the inverse relationship between unemployment and economic growth as in Okun's law. Based on the VAR methodology and the Engel-Granger cointegration test, there is no causal relationship between unemployment and economic growth and, furthermore, changes in real GDP growth do not cause changes in the unemployment rate and vice versa. The main reasons are because: first, the size of informal employment accounts for about a quarter of total employment and secondly there is structural unemployment. Their research also emphasizes that the economic policies in the Macedonian FYR are not suitable for promoting development and reducing the unemployment rate because the main source of employment comes from the public sector rather than the private sector. Informal employment accounts for about a quarter of total employment and secondly there is structural unemployment. Their research also emphasizes that the economic policies in the Macedonian FYR are not suitable for promoting development and reducing the unemployment rate because the main source of employment comes from the public sector rather than the private sector. Informal employment accounts for about a quarter of total employment and secondly there is structural unemployment. Their research also emphasizes that the economic policies in the Macedonian FYR are not suitable for promoting development and reducing the unemployment rate because the main source of employment comes from the public sector rather than the private sector.

The Relationship of Inflation with Economic Growth

Gokal and Hanif (2004) also have the same opinion where they state that Fiji is like other countries in the world, both developed and developing countries, one of the fundamental objectives of macroeconomic policy in Fiji is to maintain a strong economic growth momentum. while keeping inflation low. They also recognize that there is a huge debate in the context of the relationship between economic growth and inflation. However, in general, a low inflation rate is believed to be the foundation of a country's economic growth.

Hossin (2015) examined the relationship between inflation and economic growth in Bangladesh. Using the annual Gross Domestic Product Deflator (GDPD) data for the period from 1961 to 2013, conducting an empirical analysis using the co-integration test, error correction models and Granger Causality test. Empirical results from his research indicate a significant negative relationship in the long term between inflation and economic growth in Bangladesh as indicated by a significant negative relationship in the long term Gross Domestic Product Deflator (GDPD) towards GDP. Furthermore, the empirical results of his research show that there is a significant positive relationship in the long term GDP towards the Gross Domestic Product Deflator (GDPD). In addition to, economic growth has a positive impact on inflation. However, if the inflation rate increases much greater than the threshold inflation level, then inflation will have a negative impact on Bangladesh's economic growth. 
Barro (2013) in his research with data sets covering 100 countries in the world with a time period from 1960 to 1990 . The empirical results of his research indicate that there is a significant negative relationship between inflation and economic growth if a number of country characteristics are held constant, such as fertility rate, education level, etc. Every 10 percent increase per year will cause a decrease in GDP growth of $0.2-0.3$ percent. In the long term, this decline will affect people's standards of living.

Bruno and Easterly(1995) tested the determinants of economic growth using inflation data in 26 countries in the world that experienced an inflation crisis in the period from 1961 to 1992. The empirical results of their research set inflation at 40 percent and above as the threshold level for the occurrence of an inflation crisis in a country. The impact of inflation and economic growth is not very clear or there is an inconclusive relationship between inflation and economic growth below the threshold level. Furthermore, they stated that there was a significant negative relationship between inflation and economic growth above the threshold level. The results of the empirical robustness of their research have been tested by controlling for other factors, especially shocks such as trade shocks, political crises, and wars. Furthermore, they stated that 26 countries in the world that were experiencing an inflation crisis would be able to overcome the pre-crisis of economic growth if they were able to reduce inflation. Other results also show that the short-term inflation crisis does not cause permanent damage to economic growth.

Malla (1997) conducted an empirical analysis with data sets covering some Asian countries and countries that are members of the Organization for Economic Cooperation and Development (OECD). Empirical results from his research by controlling for other factors such as labor and capital inputs, show that there is a significant negative relationship between inflation and economic growth, including the first difference for countries that are members of the OECD. Empirical results show insignificant results for some developing Asian countries. The crucial empirical analysis of his research shows that there is an inconclusive relationship between inflation and long-term economic growth through cross-country analysis using time-series regressions with different countries and time periods.

Mallik and Chowdhury (2001) examined the relationship between inflation and economic growth in the short and long term in four South Asian economies, namely Bangladesh, India, Pakistan, and Sri Lanka. Using co-integration and error correction models from annual data released by the International Monetary Fund (IMF) International Financial Statistics (IFS), the empirical results of their research yield two things. The first empirical results show that there is a positive and significant relationship between inflation and economic growth in four South Asian countries. Their second interesting empirical result is that the sensitivity of economic growth to changes in the rate of inflation is lower than the sensitivity of inflation to changes in the rate of economic growth.

Faria and Carneiro(2001) investigated the relationship between inflation and economic growth in Brazil, which often experiences high inflation. Using a bivariate time series model, Vector Autoregression (VAR), using annual data for the time period from 1980 to 1995 , the empirical results of their research show that although there is a negative relationship between inflation and economic growth in the short term, inflation does not affect economic growth. in the long run. The empirical results of their research support the superneutrality concept of money in the long run.

Sweden (2004) investigates the relationship between inflation and economic growth whether or not it has a structural breakpoint effect on the Jordanian economy in the period from 1970 to 2003. The empirical results of his research indicate that there is a significant positive relationship between inflation and economic growth when the inflation rate is below 2 percent and the structural breakpoint effect occurs when the inflation rate is 2 percent. Above the inflation threshold, it indicates that there is a significant negative relationship between inflation and economic growth.

Mubarik (2005) estimates the inflation threshold for the Pakistani economy using annual data for the time period from 1973 to 2000. The Granger Causality Test was used to determine the threshold model and sensitivity analysis for his research model. Empirical results from his research show that inflation rates above 9 percent jeopardize Pakistan's economic growth. This empirical result on the contrary shows that an inflation rate below 9 percent actually benefits Pakistan's economic growth. Furthermore, sensitivity analysis is used to determine the robustness level of the model threshold which also shows the same thing.

Relationship between Poverty and Economic Growth 
Research conducted by Lin (2003) proves that China has succeeded in reducing as many as 450 million people from poverty since 1979. Further research shows that high economic growth between 1985 and 2001 is an important thing that helps reduce poverty. this is amazing.

Research conducted by HBhanumurthy and Hmitra (2004) shows evidence that India has succeeded in reducing poverty significantly since the 1980 s and the rate of poverty reduction has increased dramatically in the 1990s. The results of this reduction are closely related to India's impressive economic growth during that period. Another study conducted by Arndt et al (2006) showed that Mozambique succeeded in reducing poverty very quickly which is directly related to the country's economic growth. Mozambique's economic growth increased by 62 percent between 1996 and 2002 and Mozambique managed to reduce the proportion of the population living in poverty from 69 percent to only 5 percent.

Research conducted by Ravallion (2007) proves that every one percent increase in national income will reduce poverty by 4.3 percent in countries with low income inequality and will reduce poverty by 0.6 percent in countries with low income inequality. high gap.

\section{RESEARCH METHODS}

This research was conducted using a quadrant approach and a panel data approach consisting of 33 provinces and 7 years from 2011-2017, in order to obtain 231 observations. The quadrant approach is an approach to analyzing economic growth and financing high and low positions in each province in Indonesia. After the quadrant approach is carried out, then proceed with the panel regression approach.

\section{Analysis Method}

Analysis using quantitative methods with the Vector Error Correction Model (VECM). The VECM model is a restricted VAR model because there is cointegration where there is a long-term relationship between variables in the VAR system (Widarjono, 2007). Broadly speaking, the VAR/VECM analysis process can be described as follows (Tanjung and Devi, 2013):

a. The basic data that is ready must be transformed first in the form of a natural logarithm (ln), except for data that is already in the form of a percent or an index. This is done to get consistent and valid results. b. The first test is the uni unit root, to find out whether the data is stationary or still contains a trend. If the data is stationary at the level, then VAR can be performed at the level. VAR level can estimate the long-term relationship between variables. However, if the data is not stationary at its level, then the data must be derived at the first level (first difference) which reflects the data difference or change.

c. If the data is stationary in the first derivative, then the data will be tested for the existence of cointegration between variables. If there is no cointegration between variables, then VAR can only be performed on the first derivative. However, under these conditions VAR can only estimate the short-term relationship between variables. Innovation accounting will not be meaningful for the long-term relationship between variables. If there is cointegration between variables, then VECM can be performed using level data to obtain long-term relationships between variables. VECM can estimate short-term and longterm relationships between variables. Innovation accounting for the VAR label and VECM will be meaningful for long term relationships.

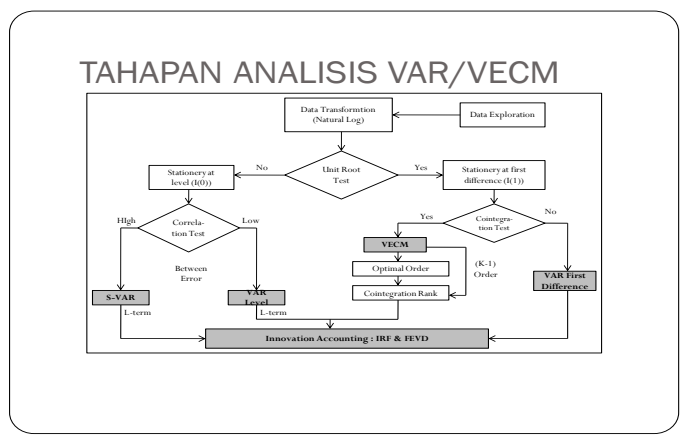

Figure 1. Stages of VAR/VECM Analysis

In this study, the assumptions that must be met in the VAR/VECM analysis were also tested as follows:

\section{Data Stationarity Test}

The stationarity test is the first step in the formation of the VAR model which is carried out to determine whether the data is stationary at level or stationary in differences to a certain degree. Stationarity test was carried out using the Augmented Dickey-Fuller (ADF) unit root test. The ADF test uses the length of lag by using the Akaike Information Criterion (AIC) criteria, in accordance with the instructions of Widarjono (2007). The length of lag in the ADF unit root test is carried out through the Akaike Information Criterion (AIC) and Schwarz Information Criteria (SIC) criteria. 
ADF testing was carried out using the Eviews software, the results statistics compared to the $t$ value of MacKinnon Critical Value. If the t-statistic is less than the Test critical value, it means that the data is not stationary. On the other hand, if tstatistic is greater than the critical value, it means that the data is stationary. It can also be seen by looking at the probability value of the ADF test results. If the value of Probability greater than the level level $(1 \%, 5 \%, 10 \%)$ then it means the data is not stationary. On the other hand, if the probability value is smaller, the level level means that the data is stationary.

To find out the non-stationary data is to compare the value of $t$ with the critical value in the MacKinnon table. The results show that the absolute value of the $t$ statistic is smaller than the absolute critical value. You can also see the valueprobability which is greater than the level level means that the variable data is not stationary. According to Winarno (2009), if from the results of the $\mathrm{ADF}$ test it turns out that the data is not stationary, then the data can be stationary, namely by making a difference.

\section{Lag Optimum}

Determination of quantity lag (order) used in the VAR/VECM model can be determined based on the Akaike Information Criterion (AIC) and Schwarz Information Criterion (SC) criteria. The lag that will be selected in this study is the model with the smallest AIC value. In this stage, the stability test of the VAR model is also carried out. Determination of the optimum lag and VAR stability test is carried out before going through the cointegration test stage.

\section{Cointegration}

The data integrity test is carried out when the data stationarity test produces non-stationary data. Cointegration testThis study was conducted to determine whether the data has a long-term relationship (cointegrated). The mutually influencing relationship is also seen from the integrity that occurs between the variables themselves and determines the model to be estimated. If there is cointegrity, then use the Vector Error Correction Model (VECM).

Cointegration test was carried out with Johansen Cointegration Test with using Eviews, if the
Trace Statistic is smaller than the critical value, the variables are not cointegrated. According to Winarno (2009), "if the Trace Statistics value is smaller than the critical value at the $5 \%$ or $1 \%$ confidence level, it can be concluded that the two variables are not cointegrated. On the other hand, if the Trace Statistics is greater than the critical value, the variables are cointegrated.

\section{Vector Autoregression Instrument}

From the estimation results of the VAR/VECM model, it can be seen the Impulse Response Function (IRF) and Variance Decomposition (VDC) of a variable against other variables or against itself IRF or VDC. The results of IRF and VDC will then be analyzed to be able to see the dynamics of the model. The IRF analysis is illustrated with a graph (graph) or table, to see how much the variable response to shock/shock is one standard deviation from the variables in the model. VDC too in the form of graphs or tables that provide an overview of the variance of a variable due to the shock of other variables or to itself. By looking at variables that are exogenous (explaining) it will be known whether the surprise of each variable is very important in forming the variance of the variable, or which variable surprise most influences changes in a variable.

One of the important requirements in time series analysis like the VECM panel is that all variables or one of them must be stationary at the 1st difference, that the research variable must be stationary or not have a unit root. Therefore, the first step in data processing is to perform a unit root test. In this case, the unit root test uses the Levine-Lin-Chu (LLC) method. The results of data processing show that with the individual intercept equation there is one stationary variable at the level of unemployment (Un) and there are 2 (two) stationary variables at the 1st difference, namely economic growth and financing. This is indicated by the probability value of each variable of 0.0000 for the variables of economic growth, financing and unemployment for the Levin, Lin and Chu t* test. Besides that, The stationary test was also compared with several other methods such as IM, Pasar and Shin W-stat, ADF and PP also showed almost the same results. The results of the unit root test with several methods are shown in Table 1. 
Table 1. Unit Root Test Results

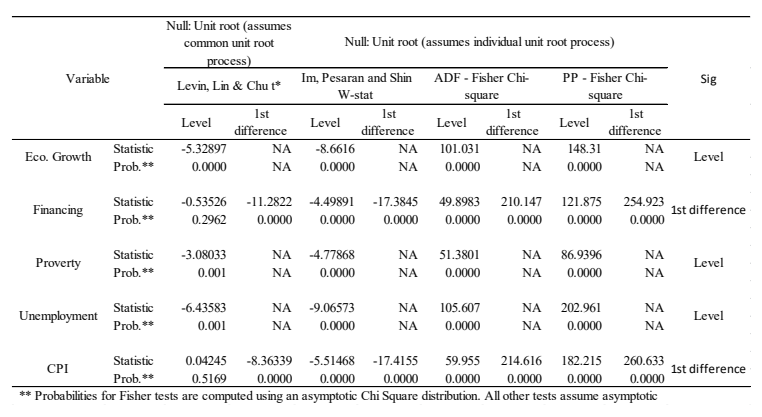

The next step is to perform a cointegration test. The cointegration test in this study uses the Pedroni Residual Cointegration Test. An equation is said to be cointegrated based on the probability value generated by the vStatistic Panel, the rho-Statistic Panel, the PP-Statistics Panel and the ADF-Statistic Panel provided that if the probability value is less than 0.05 , it means that there is cointegration (a long-term relationship between the two equations). ). Conversely, if the probability value is greater than 0.05 , it means that there is cointegration between the three variables. The results of data processing show that the probability value for each of these statistical values is greater than 0.05 as shown in Table 2.

Table 2. Cointegration Test Results Null Hypothesis: No cointegration

\begin{tabular}{ccrrr}
\hline $\begin{array}{c}\text { Hypothesized } \\
\text { No. of CE(s) }\end{array}$ & Eigenvalue & $\begin{array}{c}\text { Trace } \\
\text { Statistics }\end{array}$ & $\begin{array}{c}0.05 \\
\text { Critical Value }\end{array}$ & \multicolumn{1}{c}{ Prob.** } \\
\hline None * & 0.410093 & 194.7174 & 69.81889 & 0,0000 \\
At most 1 & 0.237208 & 93.3816 & 47.85613 & 0,0000 \\
At most 2 & 0.145034 & 41.39381 & 29.79707 & 0.0015 \\
At most 3 & 0.056937 & 11.30854 & 15.49471 & 0.1932 \\
At most 4 & 0.000277 & 0.053115 & 3.841466 & 0.8177 \\
\hline Trace test indicates 3 cointegrating eqn(s) at the 0.05 level & & \\
*denotes rejection of the hypothesis at the 0.05 level & & \\
**MacKinnon-Haug-Michelis (1999) p-values & & &
\end{tabular}

As shown in the results of the Eviews output in Table 2, the results of the cointegration test found that there is a long-term relationship between the variables studied (economic growth, financing and unemployment) therefore the data analysis tool used is the VECM Panel. Before data processing is continued with VECM, it is necessary to know the optimal lag, namely the period of time the influence of a variable on other variables gives optimal results. This is because the impact of changes in one variable on other variables does not always occur in the same year period, but can also occur in different year periods. Therefore, the most important question is how to determine the lag length and this is a problem in the model specification. This is what causes the need for determining the optimal lag. Optimal lag is the amount of lag that has a significant effect or response. The results of the Lag Length Criteria test are as shown in Table 3.
Table 3. Optimal Lag Test Results

\begin{tabular}{crrrrrr}
\hline lag & \multicolumn{1}{l}{ LogL } & \multicolumn{1}{l}{ LR } & \multicolumn{1}{l}{ FPE } & \multicolumn{1}{l}{ AIC } & \multicolumn{1}{c}{ SC } & \multicolumn{1}{c}{ HQ } \\
\hline 0 & -2.328 .46 & NA & 158428 & 23.32456 & 23.39053 & 23.35126 \\
1 & -2.096 .54 & 452.2387 & 18286.6 & 21.16539 & 21.49522 & 21.29887 \\
2 & -1.991 .42 & 200.7693 & $7,502,396$ & 20.27424 & 20.86794 & 20.5145 \\
3 & -1.919 .6 & 134.3037 & 4.295 .26 & 19.71604 & $20.57360^{*}$ & 20.06308 \\
4 & -1.885 .89 & 61.69994 & 3.601 .19 & 19.53888 & 20.66031 & 19.9271 \\
5 & -1.843 .79 & 75.35258 & $2,778,089$ & 19.27792 & 20.66321 & 19.83853 \\
6 & -1.826 .73 & 29.85186 & $2,754,762$ & 19.26734 & 20.9165 & 19.93473 \\
7 & -1.808 .97 & 30.37562 & $2,714,674$ & 19.2497 & 21.16273 & 20.02387 \\
8 & -1.726 .95 & $136,9700^{*}$ & $1.408,376^{*}$ & $18.58952^{*}$ & 20.76641 & $19.47048^{*}$ \\
\hline * indicates lag order selected by the criterion \\
LR: sequential modified LR test statistics (each test at 5\% level) & & \\
FPE: Final prediction error \\
AlC: Akaike information criterion \\
SC: Schwarz information criterion \\
HQ: Hannan-Quinn information criterion
\end{tabular}

Referring to Table 3, the optimal lag is 5, meaning that the optimal effect of a variable on other variables occurs in a time horizon of 5 periods. The next step in data analysis is the use of the VECM panel to analyze the functional relationship between economic growth, working capital financing and unemployment. As explained earlier, that there are two stationary variables on the level and one stationary on the first derivative, so the data are operationalized using VECM. Therefore, the VECM model is used to analyze the causal relationship between economic growth, working capital financing, and unemployment.

VECM model: $y \mathrm{t}=\mathrm{et}-1+\beta 1$ yt- $1+\ldots+\mathrm{n}$ yt-p $+\varepsilon \mathrm{i}$

Information,

Yt : a vector with $\mathrm{k}$ variables

$\Delta \quad$ : matrix parameters

i : error vector

because of the linear cointegration relationship, equation (1) of the VAR model will turn into the VECM equation using $\mathrm{y}_{\mathrm{t}-1}$ (first difference), namely:

$\mathrm{yt}=\mathrm{yt}-1+\sum_{i=1}^{k} \Gamma_{\mathrm{i}}^{\mathrm{yt}}-1+\mathrm{i}$

$=-(1 \mathrm{k}-1-\ldots \mathrm{p})$, and $\Gamma_{\mathrm{i}}=(\mathrm{i}+1+\ldots+\mathrm{p}), \mathrm{i}=1, \ldots \mathrm{p}-$

1

Information

$\Gamma_{\mathrm{i}} \quad$ : coefficient matrix $($ pxp), $\mathrm{j}=1, \ldots \mathrm{k}$

With

$=\sum_{i=1}^{p} \Delta \mathbf{i}-\mathrm{p}$, and $\mathrm{i}=-, \mathrm{i}=1, \ldots \mathrm{p}-1 \Gamma^{\mathrm{r}} \sum_{j=i+1}^{p} \Delta \mathrm{j}$

For hypothesis testing, trace statistics can be used $\operatorname{LRtr}(\mathrm{r} \mid \mathrm{k})=-\mathrm{T}$ i $) \sum_{i=r+1}^{k} \log (1-\lambda$

Maximum eigenvalue test

$\operatorname{LRmak}(\mathrm{r} \| \mathrm{r}+1)=-\mathrm{T} \operatorname{logi})(1-\lambda$

$\mathrm{LRtr}(\mathrm{r} \mid \mathrm{k})-\mathrm{LRtr}(\mathrm{r}+1 \mid \mathrm{k})$

For $\mathrm{r}=0.1, \ldots \mathrm{k}-1$ 
Reject $\mathrm{H} 0$ if the trace test statistic and maximum Eigen value $>$ critical value at time, or $p$ value $<$ significance value, at a significance level (1- ) of $100 \%$.

\section{Empirical Model of Vector Error Correction Model}

The following are the test results for the VECM model on the variables of economic growth, working capital financing and unemployment.

Estimated results VECM can be seen in table 8 , where the results are considered significant, the alpha value is less than 0.05 .

The results above show that in the long term economic growth is influenced by unemployment and financing. However, the effect of the financing variable is not statistically significant. Short-term growth can be explained by the economic growth in the previous year and the unemployment rate in the previous two periods. Furthermore, the financing model is relatively much explained by the variables of economic growth, unemployment and the financing itself. It can be seen from the VECM model that financing is significantly influenced by the variables of economic growth, financing, and unemployment in both one and two previous periods. For the unemployment model, it is explained by the variable of economic growth, the amount of financing, and is determined by unemployment for one and two previous periods.

Table 4. VECM . Estimation Results

\begin{tabular}{|c|c|c|c|}
\hline $\begin{array}{l}\text { Cointegrating Eq: } \\
E G(-1) \\
F M(-1)\end{array}$ & $\begin{array}{c}\text { CointEq1 } \\
1.0000 \\
(0.0752) \\
(0.5045) \\
{[-0.14895]} \\
0.6080 \\
(0.1448) \\
{[4.19778]} \\
(7.0287)\end{array}$ & & \\
\hline Error Correction: & $D(E G)$ & $\mathrm{D}(\mathrm{FM})$ & $D(U N)$ \\
\hline CointEq1 & $\begin{array}{r}(0.4743) \\
(0.0797) \\
{[-5.95487]}\end{array}$ & $\begin{array}{r}0.0028 \\
(0.0129) \\
{[0.21687]}\end{array}$ & $\begin{array}{r}(0.1137) \\
(0.0347) \\
{[-3.27718]}\end{array}$ \\
\hline $\mathrm{D}(\mathrm{EG}(-1))$ & $\begin{array}{r}(0.1270) \\
(0.0830) \\
{[-1.52894]}\end{array}$ & $\begin{array}{r}(0.0031) \\
(0.0134) \\
{[-0.23136]}\end{array}$ & $\begin{array}{c}0.0360 \\
\text { (O.0362) } \\
{[0.99574]}\end{array}$ \\
\hline$D(E G(-2))$ & $\begin{array}{r}(0.1029) \\
(0.0593) \\
{[-1.73528]}\end{array}$ & $\begin{array}{r}(0.0057) \\
(0.0096) \\
{[-0.59121]}\end{array}$ & $\begin{array}{c}0.0558 \\
(0.0258) \\
{[2.16243]}\end{array}$ \\
\hline$D(F M(-1))$ & $\begin{array}{r}0.2105 \\
(0.4989) \\
{[0.42194]}\end{array}$ & $\begin{array}{r}(0.0298) \\
(0.0806) \\
{[-0.36982]}\end{array}$ & $\begin{array}{c}0.3488 \\
(0.2173) \\
{[1.60488]}\end{array}$ \\
\hline$D(F M(-2))$ & $\begin{array}{r}0.2440 \\
(0.3980) \\
{[0.61304]}\end{array}$ & $\begin{array}{c}0.0012 \\
(0.0643) \\
{[0.01851]}\end{array}$ & $\begin{array}{c}0.0624 \\
(0.1734) \\
{[0.35968]}\end{array}$ \\
\hline D(UN(-1)) & $\begin{array}{c}0.0620 \\
(0.1587) \\
{[0.39058]}\end{array}$ & $\begin{array}{r}(0.0529) \\
(0.0256) \\
{[-2.06468]}\end{array}$ & $\begin{array}{l}(0.2746) \\
(0.0691) \\
{[-3.97330]}\end{array}$ \\
\hline$D(U N(-2))$ & $\begin{array}{r}0.1194 \\
(0.1676) \\
{[0.71216]}\end{array}$ & $\begin{array}{r}(0.0456) \\
(0.0271) \\
{[-1.68216]}\end{array}$ & $\begin{array}{r}\text { (0.1661) } \\
\text { (0.0730) } \\
{[-2.27515]}\end{array}$ \\
\hline c & $\begin{array}{r}(0.2428) \\
(0.1836) \\
(-1.32219]\end{array}$ & $\begin{array}{r}0.0284 \\
(0.0297) \\
{[0.95831]}\end{array}$ & $\begin{array}{r}(0.1512) \\
(0.0800) \\
{[-1.88962]}\end{array}$ \\
\hline
\end{tabular}

The above analysis is in accordance with research conducted by Rihab Grassa, Kaouthar Gazdar in the International Journal of Social Economics, with the theme of financial development and economic growth in GCC countries: A comparative study between Islamic and conventional finance using generalized least squares, OLS and panels data framework, in analyzing the influence of the development of Islamic finance and the development of conventional finance on the economic growth of the five GCC countries (Bahrain, Kuwait, Qatar, Saudi Arabia and the UAE) in the period 1996-2011. They argue that the development of conventional finance has a negative and significant impact on economic growth in the five GCC countries.

What is found in this study is also similar to what happened in Islamic banking in several MENA countries, which had an effect on increasing economic growth, although it was still hampered by the rules set by the relevant responsible agencies. Similar findings in Pakistan, which reveal a significant positive and dynamic two-way causal relationship in the long run between Islamic banking and real economic activity. The State Bank of Pakistan is advised to continue to promote Islamic banking as a parallel banking system to the conventional system as it has a substantial positive impact on real economic activity in Pakistan. More detailed research on the Islamic banking system on economic growth in Malaysia, Indonesia and Jordan. Types of Islamic finance such as muḍārabah, mushārakah, murābaḥa, 'istiṣnā,' ijārah as expected turned out to have an effect on Islamic financial intermediation and economic growth. Meanwhile, private sector credit and liquid liabilities do not affect Islamic financial intermediation. In developing countries, empirical investigations show that the development of Islamic banking (non-usury banks) actually supports economic growth. In addition, the cooperation of the two financing modes can increase economic growth. This new funding integration never ignores the role of conventional financing methods. Empirical investigations show that the development of Islamic banking (non-usury banks) actually supports economic growth. In addition, the cooperation of the two financing modes can increase economic growth. This new funding integration never ignores the role of conventional financing methods. Empirical investigations show that the development of Islamic banking (non-usury banks) actually supports economic growth. In addition, the cooperation of the two financing modes can increase economic growth. This new 
funding integration never ignores the role of conventional financing methods.

Another different case, a study in Turkey, which shows that financing carried out by Islamic banking does not have a significant effect on economic and industrial development. The main reason for this result is the small percentage of Islamic banking in the overall banking system. They urged to improve the function of Islamic banking in order to contribute more to the country's economy. This result is in line with the findings of this study that non-investment financing from Islamic banking actually reduces economic growth.

What about unemployment? This indicator is also considered as a factor of economic growth because of the contribution of the existing labor supply. The greater the unemployment, the less labor resources available so that economic actors can use them optimally. The number of unemployed will cause an economic contraction. If there are workers who are not absorbed in work or unemployed, it will slow down economic growth. As shown in the model results, unemployment has a negative effect on economic growth. If unemployment increases by 1 percent, it will have an impact on a decline in economic growth of around -0.41 percent. The results of this study are in line with the research of Al-Habees and Rumman. They used the Comparison-Simulation Approach to examine the relationship between unemployment and economic growth in Jordan and several Arab countries. They conclude that in Arab countries there is a weak relationship between the unemployment rate and economic growth. While the relationship between unemployment and economic growth in Jordan shows a negative relationship where an increase in economic growth reduces the unemployment rate. Changes in the unemployment rate in Jordan will lead to an increase in the natural growth rate of the Jordanian economy by $5.90 \%$. While the relationship between unemployment and economic growth in Jordan shows a negative relationship where an increase in economic growth reduces the unemployment rate. Changes in the unemployment rate in Jordan will lead to an increase in the natural growth rate of the Jordanian economy by $5.90 \%$. While the relationship between unemployment and economic growth in Jordan shows a negative relationship where an increase in economic growth reduces the unemployment rate. Changes in the unemployment rate in Jordan will lead to an increase in the natural growth rate of the Jordanian economy by $5.90 \%$.
A study in Nigeria conducted by Victoria Kenny S applied the Granger Causality VAR approach to determine the direction of the relationship between unemployment (UNEMP) and the rate of economic growth (RGDP) for the period 1981-2016. The main finding of this study shows a unidirectional relationship of VAR between unemployment and economic growth, which implies that the level of economic activity does not interfere with the causes of unemployment in Nigeria. Therefore, the government should improve the viability of small and medium-sized enterprises which can help create more jobs, reduce unemployment and lead to sustainable real output growth, which in turn is expected to create increased employment in the economy.

Alotaibi Mohamed Meteb conducted a study to answer, is economic growth enough to reduce unemployment among Saudi citizens? The results show a positive relationship between employment and real income, real investment, real government spending, and the value of real exports. On the other hand, there is also a negative relationship between employment and the value of real imports. Economic growth is inadequate in lowering the unemployment rate among all Saudi citizens. There is also an inverse relationship between the unemployment rate and economic growth which is not working effectively in the Saudi economy. Saudi nationals prefer to work in the government sector than in the private sector, therefore the Government is advised to encourage Saudi citizens to work in the private sector.

\section{Impulse Response Functions}

Impulse response function (IRF) shows the response of an endogenous variable to changes that occur in other endogenous variables in a dynamic VAR system. IRF can be used to examine the effect of a surprise standard deviation of an innovation variable on the current or future value of endogenous variables (Arianto, et. al, 2010). The innovation variables referred to in this study are economic growth, financing and unemployment when these variables are placed as explanatory variables for one of the two.

In the first period, there was almost no response from economic growth to financing and unemployment. The response tends to move positively until it enters the second, third and fourth periods. Then in the fifth period and so on, the response of economic growth to financing and unemployment is getting smaller until it reaches balance. This is shown by the graph on the top right 
which shows the movement of the IRF curve closer to the horizontal line from the fifth period to the following periods. The impulse response function (IRF) between economic growth and income inequality is shown in Graph 2.

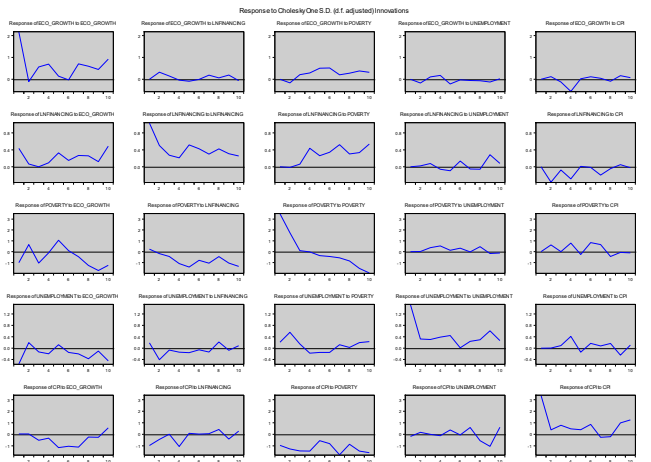

Graph 2 Impulse Response Function (IRF) Economic Growth and ....

The response to financing for economic growth was positive in the first, second and third periods, and tended to decline in subsequent periods. The occurrence of a shock in economic growth tends to result in a decline. The response of financing to economic growth is getting smaller until it enters the tenth period towards balance.

\section{Variance Decomposition Analysis (VDA)}

Variance decomposition (VD) shows the proportion of forecast variance of a variable caused by innovation (either from the variable itself or not). VD can be used to find out how big the predictive variance of a variable comes from the innovation variable.It can be seen that the dominant economic growth is influenced by economic growth itself, financing and unemployment but is more dominantly explained by economic growth itself, where the variance decomposition value of economic growth increases significantly from each period. While the financing variable is dominantly explained by economic growth and financing itself, while the unemployment variable is relatively small. The unemployment variable is more dominantly explained by financing and unemployment is shown in table 9.
Table 5. Decomposition Variants of Economic Growth, Financing and Unemployment

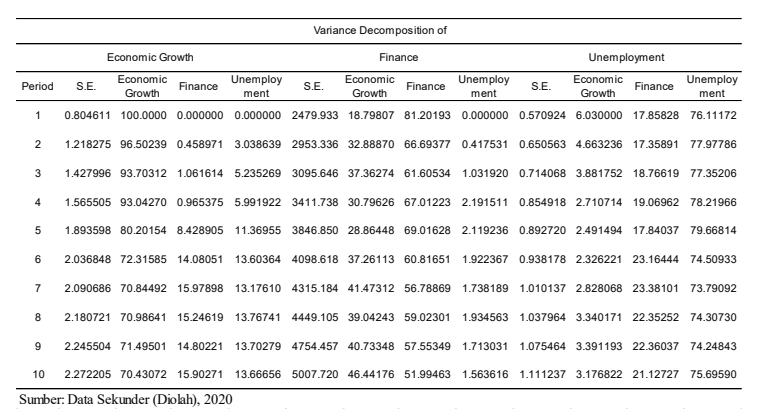

\section{Conclusion}

The results of this study indicate that financing and unemployment have a significant effect on economic growth in Indonesia. The results of the study prove that changes in financing have a major impact on economic growth. An increase in the unemployment rate will have a negative impact on the level of the economy in the long run. Financing provided by Islamic banks is very useful in encouraging economic growth. The government is urged to make regulations in favor of Islamic banking. Furthermore, the Government is also advised to control the unemployment rate so that economic growth can increase as expected. 


\section{Reference}

Abduh Muhammad, Mohd Azmi Omar. Islamic banking and economic growth: the Indonesian experience. International Journal of Islamic and Middle Eastern Finance and Management, Vol.5 Issue:1, pp.35-47. 2012.

Abdul Rafay and Saqib Farid. Dynamic Relationship between Islamic Banking System and Real Economic Activity: Evidence from Pakistan. JKAU: Islamic Eco., Vol. 30 No. 2, pp: 97-116 (July 2017) DOI: 10.4197 / Islec. 30-2.10

Abdul Rahim Abdul Rahman. Islamic microfinance: an ethical alternative to poverty alleviation. Humanomics, Vol. 26. 2010.

Bidabad, B, and Allahyarifard, M. "Accounting Procedures for Profit and Loss Sharing (PLS) Banking”.(http://www.bidabad.com/doc/PLS-accounting-en.pdf Retrieved on 28 February 2016).

Boldeanu, Florin Teodor \& Constantinescu, Liliana. The main determinants affect economic growth. Bulletin of the Transylvania University of Braşov. Series V: Economic Sciences • Vol. 8 (57) No. $2-2015$.

Development in Turkey? IKONOMIKA: Journal of Islamic Economics and Business Volume 2, No 1 (2017) ISSN: 2527-3434 (PRINT) - ISSN: 2527-5143 (ONLINE) Page : 93 - 102.

Driscoll, John C. Does Bank Lending Aect Output? Evidence From the US States. Forthcoming, Journal of Monetary Economics.

Durrani, Muhammad Kashif Khan, Abid Usman, Muhammad Imran Malik, Shafiq Ahmad. Role of Micro Finance in Reducing Poverty: A Look at Social and Economic Factors. International Journal of Business and Social Science, Vol.2, No.21 [Special Issue] pp.138-144.2011.

Faria, J. and Carneiro, F. Does High Inflation Affect Growth in the Long and Short Run? Journal of Applied Economics, Volume 4 No.1, 89-105. 2001.

Florin Teodor Boldeanu and Liliana Constantinescu. The main Determinant Affecting Economic Growth. Bulletin of the Transylvania University of Braşov Series V: Economic Sciences. Vol. 8 (57) No.2 2015.2015 .

Furqani, Hafas and Mulyany, Ratna. Islamic banking and economic growth : Empirical evidence from Malaysia. Journal of Economic Cooperation \& Development. Vol 30. Issue 2. 2009.

Gokal, Vikesh and Subrina Hanif. Relationship Between Inflation and Economic Growth, Working Paper, Economics Department Reserve Bank of Fiji, Fiji. 2004.

Grassa, Rihab, Kaouthar Gazdar. Financial development and economic growth in GCC countries: A comparative study between Islamic and conventional finance. International Journal of Social Economics. Vol. 41, Issue: 6, pp. 493-514. 2014.

Gumel, Gambo Babandi, Norma MD Saad, Salina HJ Kassim Assessing. The Impact of Islamic Microfinance on Poverty Alleviation in Northern Nigeria. Journal of Islamic Economics, Banking and Finance, Vol.10, No.4, pp37-49. 2014.

Hafnida Hafnida, Selamat Maamor, \& Hussin Abdullah. An Empirical Study of the Relationship between Islamic Modes of Finance and Financial Intermediation. International Journal of Business and Management; Vol. 10, No. 7; 2015 Canadian Center of Science and Education.

HBhanumurthy and HMitra (2004), Economic Growth, Poverty, and Inequality in Indian States in the Prereform and Reform Periods, Asian Development Review, vol. 21, no. 2, 2004, pp. 79-99. 
Imran, Muhammad, Khurrum S. Mughal, Aneel Salman, Nedim Makarevic. Unemployment and Economic Growth of Developing Asian Countries: A Panel Data Analysis European Journal of Economic Studies, Vol.13, Issue 3, 2015.

Jamel Boukhatem and Fatma Ben Moussa. The effect of Islamic banks on GDP growth: Some evidence from selected MENA countries. Borsa Istanbul Review 18-3 (2018) 231e247 http://www.elsevier.com/journals/borsa-istanbul-review/2214-8450

Kreishan, Fuad M. Economic Growth and Unemployment: An Empirical Analysis Journal of Social Sciences, vol. 7 No. 2: 228-231, 2011.

Lin (2003), Economic Growth, Income Inequality, and Poverty Reduction in People's Republic of China, Asian Development Review, vol. 20, no. 2, 2003, pp. 105-24.

Malla, S. "Inflation and Economic Growth: Evidence from a Growth Equation," mimeo, Department of Economics, University of Hawai'I at Monoa, Honolulu (1997).

Mallik, Girijasankar and Anis Chowdhury. Asia-Pacific journal of rural development, Volume 8, No.1, 2001.

Md. Shakhaowat Hossin. The Relationship Between Inflation and Economic Growth of Bangladesh: An Empirical Analysis from 1961 to 2013. International Journal of Economics, Finance and Management Sciences. Vol. 3, No. 5, 2015, pp. 426-434.

OJK. 2018. History of Islamic Banking. (https://www.ojk.go.id/id/kanal/syariah/ aboutsyariah/Pages/History of Banking-Syariah.aspx, accessed on 10 November. 18).

OJK. Sharia Banking Statistics (SPS). Jakarta. 2018.

Prastowo. (2018). The effect of Islamic banking financing on economic growth: Empirical study in 13 countries. Haluya: Indonesian Journal of Multidisciplinary Islamic Studies. 2(1), January.

Rahman, M Mizanur. Islamic micro-finance program and its impact on rural poverty alleviation. International Journal of Banking and Finance, Vol.7, Issue:1, No.1 pp.119-138. 2010.

Rahman, M. Mizanur and Fariduddin Ahmad. Impact of microfinance of IBBL on the rural poor's livelihood in Bangladesh: an empirical study. International Journal of Islamic and Middle Eastern Finance and Management, Vol.3 Issue:2, pp.168-190. 2010. Raja Gradindo Persada. 2013.

Ravallion (2007), Inequality is Bad for the Poor, Chapter 2 in Inequality and Poverty Re-examined, ed Jenkins and Micklewright, Oxford.

Robert J. Barro "Inflation and Economic Growth" Annals of Economics And Finance Journal Vol 14 Issue 1,2013 page 85 .

Ruzima, Martin and Veerachamy, P. Impact of Implation on Economic Growth: A Survey of Literature review. Journal of Golden Research Thoughts, Vol 5. Issue 10. 2016.

Sadiku, Murat, Alit Ibraimi, Luljeta Sadiku. Econometric Estimation of the Relationship between Unemployment Rate and Economic Growth of FYR of Macedonia. Procedia Economics and Finance Vol. 19, $69-81,2015$.

Saida Daly and Mohamed Frikha. Banks and economic growth in developing countries: What about Islamic banks? Cogent Economics \& Finance, ISSN 2332-2039, Taylor \& Francis, Abingdon, Vol. 4, Iss. 1, pp. 1-26,http://dx.doi.org/10.1080/23322039. 2016.1168728.

Sakai, Minako. Growing together in partnership: Women's views of the business practices of an Islamic Savings and Credit Cooperative (Baitul Maal wat Tamwil) in Central Java, Indonesia. Women's Studies International Forum, Vol.33, Issue:4, pp.412-421. 2010. 
Serhat Yüksel and smail Canöz. Does Islamic Banking Contribute to Economic Growth and Industrial.

Shahbaz, Muhammad, Saleheen Khan, Mohammad Iqbal Tahir. The dynamic links between energy consumption, economic growth, financial development and trade in China: Fresh evidence from multivariate framework analysis. Energy Economics. Vol 40. Pp. 8-21. 2013.

Shirazi, Asim Shah. Targeting and Socio-Economic Impact of Microfinance: A Case Study of Pakistan. Islamic Economic Studies, Vol.20, No.2, pp 1-28. 2012.

Sweidan, OD Does Inflation Harm Economic Growth in Jordan? An Econometric Analysis for the Period 1970-2000. International Journal of Applied Econometrics and Quantitative Studies, Vol. 1-2, pp. 41-66. 2004.Tabash, M., I. \& Dhandar, R., S. (2014). Islamic banking and economic growth: An empirical evidence from Qatar. Journal of Applied Economics and Business. 2(1), March.

Usman, Abubakar Sadiq and Rosmaini Tasmin. The Role of Islamic Micro-finance in Enhancing Human Development in Muslim Countries. Journal of Islamic Finance, Vol.5 No.1 pp 053-062. 2016.

Widiyanto bin Mislan Cokro Hadisumarto Abdul Ghafar B. Ismail. Improving the effectiveness of Islamic micro-financing. Humanomics, Vol.26, Issue:1 pp. 65-75. 2010.

World Bank. Social Capital, Empowerment, and Community Driven Development .http://info.worldbank.org/etools/bspan/PresentationView.asp?PID=936\&E ID=482, May 11, 2005.

Yasir Ali Mubarik. Inflation and Growth: An Estimate of the Threshold Level of Inflation in Pakistan. SBP Research Bulletin, vol. 1, 35-44. 2005. 